Mehrsprachigkeitskonzept - Tertiärsprachenlernen - Deutsch nach Englisch / B. Hufeisen, G. Neuner. - Strasbourg: Europarat, 2003. 249 s. 6. Krumm H.-J. Sprachenpolitik und Mehrsprachigkeit / H.J. Krumm / Mehrsprachigkeitskonzept - Tertiärsprachenlernen Deutsch nach Englisch / B. Hufeisen, G. Neuner. - Strasbourg: Europarat, 2003. - 249 s. - S. 35-48. 7. Neuner G. Mehrsprachigkeitsdidaktik und Tertiärsprachenlernen: Grundlagen Demensionen - Merkmale [Електронний pecypc] / G. Neuner. München : Hueber, 2009. - Режим доступу: www.hueber.de/ mehrsprachigkeitsdidaktik 8. Schwenk H. Konstellationen in der Deutschdidaktik im Jahre 2010 [Електронний pecypc] / H. Schwenk. Режим доступу: http://ebookbrowse.com/ konstellationen-in-derdeutschdidaktik-im-jahre-2010-helga-schwenk-1-doc-d62537747

9. Schwenk H. Sprachunterricht im europäischen Kontext / H. Schwenk // Zeitschrift für Europa Studien. - 2002. - №3. - Band 2. S. 113-131. 10. Spielkamp Th. Thesen zur aktuellen Entwicklung des Fremdsprachenlernens in Deutschland ГЕлектронний ресурс] / Th. Spielkamp. - Режим доступу: konferencje.frse.org.pl/ img/ Mfile/308/file.pdf

УДК 574(07):908

С. М. Грищенко,

здобувач,

ДВНЗ «Криворізький національний університет»

\title{
IНТЕРАКТИВНІ ІГРОВІ КОМП'ЮТЕРНІ ТЕХНОЛОГІЇ У ВИВЧЕННІ ЕКОЛОГІЇ
}

У статті розкрито зміст $i$ структуру інтерактивних ігрових комп'ютерних технологій, показано особливості їх використання у вивченні екології.

Ключові слова: гра, ігрові технології, екологія.

В статье раскрыты содержание и структура интерактивных игровых компьютерных технологий, показаны особенности их использования при изученни экологии.

Ключевые слова: игра, игровые технологии, экология.

The article deals with the content and structure of the interactive gaming computer technology in the study of ecology.

Key words: game, game technology, ecology.

У сучасному суспільстві відбуваються складні соціальні, політичні, економічні процеси, що мають переважно глобальний характер. Глобалізація, світовий перерозподіл праці та інформатизація - це процеси масштабні, потребують опису 
та осмислення. Динамічно трансформуються соціальні умови в Україні, нарощуються вимоги до якості освіти, до формування особистості, характеризуються не репродуктивним, а творчим типом мислення, ініціативною самостійністю в прийнятті рішень. Це потребує пошуку нових підходів у навчанні. Процес навчання в сучасному світі повинен грунтуватися не на трансляції готових знань, а на створенні умов до творчої активності. За таких умов роль викладача повинна змінитися. Із транслятора знань він повинен стати транслятором смислів. Усе більшого визнання знаходять активні групові методи навчання. 3-поміж них імітаційні та ділові ігри, комп’ютерні системи на зразок «Що буде, коли...». Їх склад відображає логіку практичної діяльності, тому вони є ефективним засобом засвоєння знань, формування умінь, об'єднання та інтеграції знань в єдину систему. Ігрові технології на відміну від традиційних методів навчання призначені для того щоб підготувати розум до дослідження, розуміння, а не просто наповнити його знаннями. Освітня гра, оперуючи швидше поняттями «досвід» i «розуміння», ніж поняттям «знання», відкриває все більшу можливість для смислової побудови освітнього процесу. Досвід, отриманий у грі, для того, щоб увійти в систему компетентності учня, повинен бути витлумачений і виведений в поле смислів.

Mema cmammi : дослідити роль ігрових комп'ютерних технологій у підвищенні ефективності навчального процесу.

У такій діяльності повинна виявитися нова роль викладача - тлумача досвіду. Більше того, навчальний процес, у центрі якого знаходиться тлумачення та породження сенсу, буде слугувати ефективним засобом розвитку у школяра здатності до розуміння та осмислення.

На відміну від традиційних форм освітнього процесу, гра більш вільно співвідноситься з поняттями місця і часу, дозволяє моделювати рішення, що мають глобальні наслідки, віддалені в часі та просторі. Така побудова освітнього процесу сприяє виробленню здатності до оцінки довгострокових наслідків своїх дій і формування відповідальності за майбутнє. Гра дозволяє учасникам подивитися на суспільне явище зсередини й отримати особистий досвід, загальний, притому, для всієї групи гравців.

Ще одна важлива особливість ігрових форм навчання орієнтація на вільні та самостійні дії кожного учасника. Зворотний зв'язок гравці отримують від інших гравців або побу- 
дованої за певними законами моделі, а не від викладача. Гравці виконують роль суб'єктів, які приймають рішення або досліджують модель. Очевидно, досвід, отриманий отже, має особливу переконливу силу.

Активні методи навчання дозволяють підвищити рівень засвоєння й осмислення інформації під час вивчення проблем екології. Гра особливо ефективна там, де необхідно вийти за межі схем. Коли справа стає умовною, воно відбувається за логікою можливого. Отже, гра стає засобом моделювання (на рівні поняття і на рівні дії) нових умов дійсності (включаючи екстремальні), методом пошуку нових способів досягнення поставленої мети. Однак перш ніж учні почнуть «грати», вони повинні зануритися в середовище, елементом якої є досліджуваний об'єкт. Моделювання в межах гри виконує подвійну функцію: 1) моделювання дозволяє представити в абстрактному ігровому світі всі ті вияви світу реального, всі значущі характеристики відтворюваного явища, які потрібні для побудови контексту розуміння; 2) закладені в гру моделі складних процесів і явищ можуть бути тим змістом, який засвоюють учасники гри.

Виявлення неповноти наших уявлень про гуманітарні, людські, екологічні аспекти моделі сучасного світу вимагає міждисциплінарної методології, яка відповідає фундаментальним науковим положенням. Структура цього завдання виявилася настільки складною, що вимагає вміння керувати багаторівневим процесом. Відзначається несумісність парадигм світоустрою: фізичної (техносфера) і натуралістичної (біосфера) картин світу, виокремлених В. Вернадським, і сьогодні представлених у сфері стандартизації (табл. 1). Цим пояснюється фрагментарність уявлень різних професійних груп, що залишаються при «своїй правді», i не готових прийняти картину сучасного світу від сусідів. Вирішальною умовою успіху стає вибір методу об'єднання різних уявлень у «загальну картину», здатну об'єднати зусилля в конструктивному розробленні моделі.

Цим умовам відповідає системна динаміка, яка об'єднує як точні, так і недостатньо точні поняття, показники гуманітарного ряду: інтереси, потреби тощо, наприклад, бажану кількість членів сім’ї, справедливий розподіл приготованої їжі. Системна динамічна модель містить більше двохсот змінних і п'ять основних показників: народонаселення, ресу- 
рси, промислова продукція, сільськогосподарська продукція, забруднення.

Завдання управління такою багатокомпонентною, різноплановою й нелінійної системою за складністю перевершує можливості раціональної формалізації управління. Причина цього - включення інтересів людини (людства) в «сталий розвиток». Там, де в завданні включено інтереси людини, стандартні прийоми оптимізації не працюють.

Таблийа 1

Стандартизація техносфери і властивості екосистем

\begin{tabular}{|c|c|}
\hline $\begin{array}{c}\text { Вимоги до технічних стандартів (Зань- } \\
\text { ко, 1982, Урванцев, 1984) }\end{array}$ & Властивості екосистеми \\
\hline $\begin{array}{c}\text { Скорочення невиправданого різнома- } \\
\text { ніття }\end{array}$ & Біологічна різноманітність \\
\hline Уніфікована мова & Різноманітність мов \\
\hline $\begin{array}{c}\text { Систематизація статистичних предме- } \\
\text { тів, понять та явищ }\end{array}$ & Динамічність і \\
Мепередбачуваність явищ
\end{tabular}

Завдання управління в цьому випадку вимагає перебору різнобічних рішень, часто 3 домінуванням інтуїтивних і вироблення правил управління надскладними системами, методів навчання їм. Слідуючи принципам «розумної обережності» $\mathrm{i}$ «розумної достатності» можна зробити висновок: управління розвитком складових екосистем слід розглядати як складну інтелектуальну задачу, що вимагає розроблення нових принципів інструментарію.

Відмінність дидактичної моделі навчання, спрямованої на формування екологічної грамотності, від традиційного навчання, полягає в тому, що учневі меншою мірою пропонується «дивитися, слухати, писати, відтворювати інформацію» до технологій, під час використання яких доводиться «думати», «обговорювати», «працювати разом», «розуміти людину», «розв'язувати проблеми» (згідно зі смисловими асоціаціями учнів). Експериментально отримані дані свідчать про ефективність моделі формування екологічної грамотності не тільки в розвитку інтересу до засвоюваних знань, навичок, а й ініціації творчої активної діяльності, сенсу освіти; розвиток смислової й емоційно-чуттєвої сфер особистості; про особистісне включення в навчання, розвиток системного мислення (наприклад, у цьому випадку асоціації відображають багато- 
гранне, цілісне уявлення уроку) [1, с. 17]. Відомо, що широта, варіативності асоціацій є ознаками, що покладені в основу розвитку здатності до мислення, зокрема прогностичного.

Необхідна інтегрованість різних методів, форм, засобів навчання в освітньому середовищі навколо системоутворювальної ідеї формування екологічної грамотності та критеріїв іiі сформованості. Важливий облік індивідуальних особливостей людини в навчанні. Це створює в освітньому середовищі умови, необхідні для ефективного виховання і розвитку особистості, що володіє екологічною грамотністю. Необхідно удосконалити методичну підготовку вчителів-предметників і майбутніх фахівців, здатних виховувати екологічно грамотні покоління молоді. Ігрові технології повною мірою цьому сприяють.

У роботі [2] викладена базова філософія і функціональні можливості гри EcoMUVE (Multi-User Virtual Environment) (багатокористувачеве віртуальне навколишнє середовище) для вивчення структури екосистеми і формування уявлень про причинні зв'язки в ній. Ігровий проект MUVE - потужний освітній інструмент, який дозволяє користувачам уповільнювати або прискорювати час, рухатися в просторі, змінювати масштаб просторових об'єктів, записувати результати спостережень за допомогою віртуальних інструментів. Наприклад, в імітаційному водоймищі EcoMUVE використовує підводний човен і «мічений атом» для того, щоб сформувати екологічні поняття збереження маси і пов'язати їх 3 процесами розкладання (рис. 3). EcoMUVE дозволяє учням виявляти і взаємодіяти з компонентами складних зразків екосистеми водойми (рис. 4). Так, наприклад, під час вивчення проблеми масового цвітіння водоростей у водоймищі, вони мають змогу активно досліджувати екосистему 3 реалістичною графікою і віртуальними вимірювальними приладами.

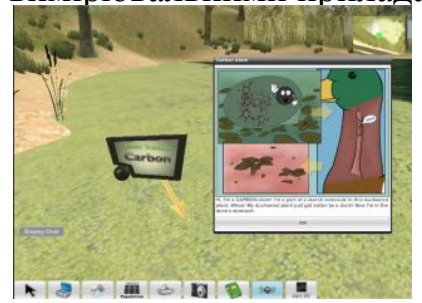

Pис. 3. Скриншот з гри ЕсоMUVE ілюструє використання «міченого атома» для дослідження руху атомів вуглещңю в навколишнє середовище. 
У роботі [2] підкреслюються переваги персоніфікованого підходу та інтерактивних методів навчання за допомогою віртуального навколишнього середовища EcoMUVE, які допомагають активізувати увагу і захопити учнів.

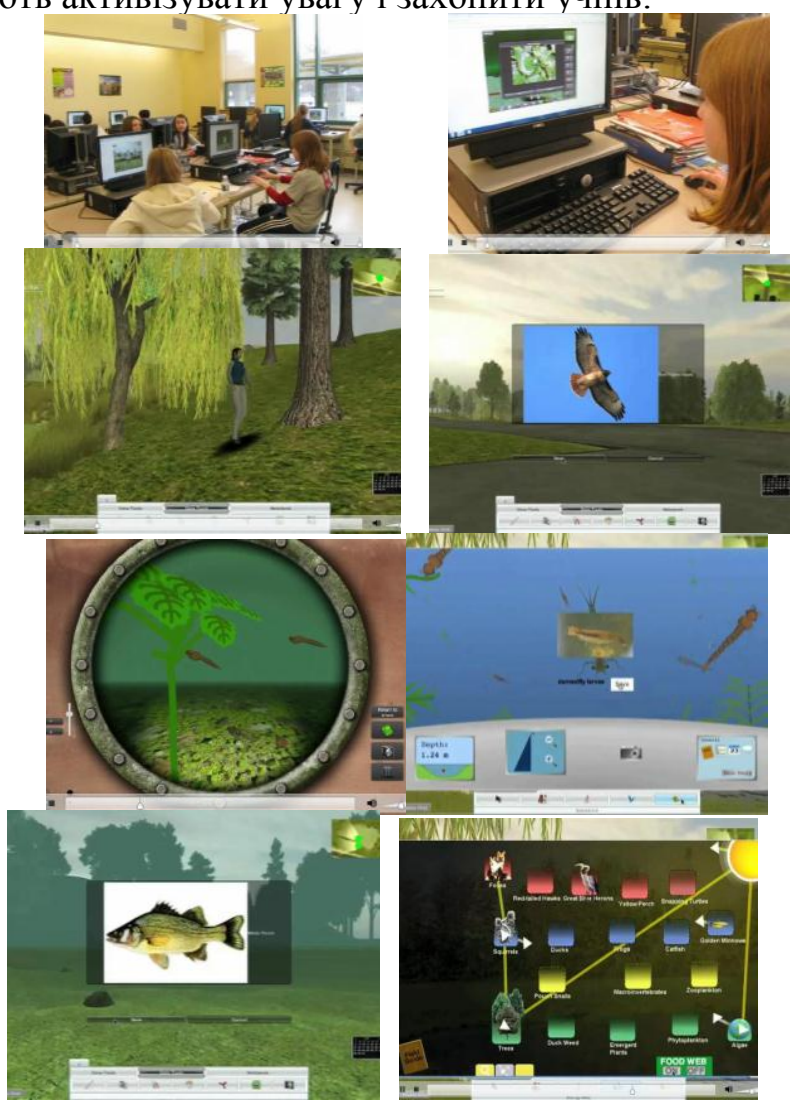

Рис. 4. Вивчення екосистеми й причинних зв 'язків у ній в грі EcoMUVE

Особливо слід відзначити запропоновані Dede нові методи оцінювання знань учнів [2]. Вони грунтуються на можливості запису кожного руху, який учні роблять, граючи в MUVE (рис. 5). Відомі і широко використовуються методи оцінювання, що передбачають тестові випробування, здаються неймовірно обмеженими порівняно з великою кількістю викликів і проблем реального світу, які можуть бути продемонстровані в іграх на основі віртуальної реальності. Dede i його колеги вже починають використовувати цей підхід у Virtual 
Performance Assessment project - проект вимірювання характеристик віртуальної роботи, який є інструментом оцінки здатності учнів середньої школи зрозуміти складні причинні зв'язки у водоймищах та лісових екосистемах.
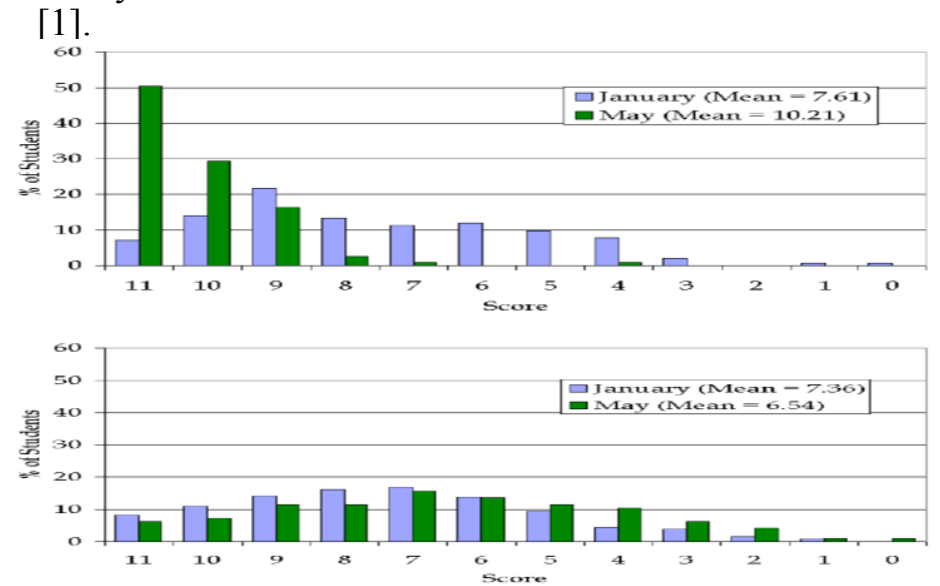

Puc. 5. Pre-(January) i post (May)-тестування, зроблені в Gen Bio секиіях University of Tennesseе в прочесі викладання: A - результати навчання із застосуванням кількісної оцінки якості засвоєння матеріалу; B - без такого контролю; Score - число правильних відповідей.

Перспективним напрямком у вивченні екології є краєзнавчий підхід з використанням технології Google Планета Земля (англ. Google Earth) [3]. Це проект компанії Google, у межах якого в мережі Інтернет розміщено супутникові фотографії всієї земної поверхні. Використання проекту доцільне як для вивчення екосистем, так і як фундамент створюваних ігрових програм. Нині програма-pecyрс Google Earth («віртуальний глобус») і спрощений 3D-редактор SketchUp являють собою складові компоненти єдиної родини програмних продуктів, тому користувач може легко переносити інформацію з одного пакету в іншій. Відповідно, і ці програми, i, що особливо важливо, їх синхронізація, залучення громадськості до наповнення інформацією, є абсолютно унікальним, не має аналогів. SketchUp - дуже зручна програма для швидкого створення і редагування тривимірної графіки, використовуваної в ігрових проектах. Порівняно з багатьма популярними пакетами пропонований володіє низкою переваг, які полягають, у першу чергу, у майже повній відсутності вікон попередніх 
налаштувань. Усі геометричні характеристики задаються 3 клавіатури в полі Value Control Вох (Поле Контролю Параметрів; знаходиться в правому нижньому кутку робочого сектору, праворуч від напису Measurements - «Система Мер») під час або відразу після завершеннә дії інструменту. Ця особливість дозволяє уникнути необхідності налаштовувати кожен інструмент перед його застосуванням, а потім редагувати можливі невраховані помилки. SketchUp інтуїтивний і дуже простий у використанні, оскільки зроблено з розрахунком на непрофесіоналів, і дозволяє відносно швидко і просто досягти бажаного результату, використовуючи звичні 3 дитинства інструменти - «лінійку», «олівець», «транспортир», «ластик» у трьох площинах.

Імпорт растрової графіки має кілька можливостей: вставка образу як окремого об'єкта в якості текстури і в якості основи для відновлення тривимірного об'єкту за фотографією. Експорт у формат Jpg здійснюється в якості знімка 3 робочого сектору вікна програми. Подальше редагування експортованого файлу у відповідних додатках може здійснюватися без будь-яких обмежень, а плагін VRay for SketchUp (англ.) дозволяє візуалізувати тривимірні сцени.

У програмі є бібліотеки компонентів, матеріалів і стилів робочого сектору, які можна поповнювати своїми елементами. $€$ змога встановлювати тіні відповідно до заданих широтою, довготою, часом доби і року. Додатково програма дозволяє створювати макроси для повторюваних дій на мові Ruby i додавати для них у меню нові пункти, також доступна функція завантаження та використання численних готових скриптів, наданих іншими користувачами.

Починаючи 36 версії, у програмі 3'явилася можливість синхронізувати моделі з додатком Google Earth. У процесі моделювання копій архітектурних споруд можна легко імпортувати аеро- або супутникову фотографію потрібного будинка, а також топографію місцевості 3 Google Earth, а потім «будувати» віртуальну будівлө-модель на фундаменті, яким буде супутникова фотографія будівлі-прототипу. Для того, щоб побачити щойно створену в програмі SketchUp 3Dмодель «у віртуальному житті» на рельєфі Google Earth, досить натиснути іконку на панелі інструментів. Для обміну інформацією між програмами достатньо, щоб обидві вони були встановлені на комп'ютері користувача і одночасно відкриті в момент роботи. 
У синхронізації додатків є й альтруїстичний аспект: будьхто бажаючий може самостійно збагатити додаток Google Earth побудованими моделями вже наявних будівель.

Розглянуті вище програмні технології покладено в основу ігрового проекту «ЕкоКривбасс». Завданням цієї імітаційної гри є вивчення наслідків викиду в повітря речовин, шкідливих для здоров'я мешканців Кривого Рогу, на одному з його підприємств. Ігровий майданчик сформовано на основі реальних фотографій поверхні Кривбасу, узятих із програми Google Earth за допомогою технологіï Google SketchUp. Для побудови великих за обсягом сцен застосовувалися об'єкти 3 бібліотеки 3D Warehouse. Учні можуть задавати розташування джерела, обсяг і геометрію викиду, швидкість і напрям вітру. Програма дозволяє в динаміці спостерігати, вимірювати i аналізувати параметри забруднених поверхонь міста $\mathrm{i}$ його околиць.

У грі використано результати НДР, яка виконується в ДВНЗ «Криворізький національний університет» під керівництвом проф. В. Моркуна «Розробка розподіленої системи збирання та оброблення інформації про поточний стан навколишнього середовища для моделювання екологічної ситуації на гірничих підприємствах з використанням інноваційних енергоефективних і ресурсозберігаючих технологій» [4, c. 342].

Отже, імітаційні ігрові технології на основі віртуального простору, що формується з використанням супутникових фотографій земної поверхні, дозволяють сповільнювати або прискорювати час, рухатися в просторі, змінювати масштаб просторових об' єктів, записувати результати спостережень за допомогою віртуальних інструментів, виявляти, досліджувати і взаємодіяти 3 компонентами екосистеми, сформувати уявлення про структуру і причинні зв'язки в ній, а також моделювати вплив природних катаклізмів і людської діяльності на навколишнє середовище.

Сценарій і відеооформлення комп'ютерної рольової гри «Екологія Кривбасу» побудовані на основі реальних характеристик, супутникових і зроблених учнями фотографій Криворізького промислового регіону.

\section{Література}

1. Смирнова Е. В. Исследовательский подход и имитационные игры в экологическом образовании школьников [Электронный ресурс] / Смирнова Е. В. - Режим доступа: http://www.ag- 
students.narod.ru 2. Википедия с описаним SketchUp [Электронный pecypc] / Википедия. - Режим доступа: http://ru.wikipedia.org/ wiki/SketchUp. 3. Википедия с описанием Google Earth. [Электронный ресурс] / Википедия. - Режим доступа: http://ru.wikipedia.org/ wiki/GoogleEarth. 4. Моркун Н. В. Інформаційна багаторівнева система управління складними об'єктами / Моркун Н. В., Артюхов О. В. // Матеріали конференції «Сталий розвиток промисловості та суспільства». - Кривий Ріг, 2012. - Том 1. - С. 342-343.

УДК 378.147: 37.013 .42

I. I. Доброскок,

доктор пед. наук, професор, ДВНЗ «Переяслав-Хмельницький державний педагогічний університет імені Г. Сковороди»

\section{РІВНІ ЕФЕКТИВНОСТІ ОРГАНІЗАЦЇ̈ НАВЧАЛЬНОЇ ДІЯЛЬНОСТІ МАЙБУТНІХ СОЦІАЛЬНИХ ПЕДАГОГІВ}

У статті розкрито рівні ефективності організачї навчальної діяльності майбутніх соціальних педагогів. Охарактеризовано групи навчальних елементів, рівні сформованості знань відповідно до характеристики діяльності майбутніх фахівиів.

Ключові слова: рівні ефективності, організачія навчальної діяльності, сочіальні педагоги.

В статье раскрыты уровни эффективности организаиии учебной деятельности будуших сочиальных педагогов. Охарактеризованы группь учебных элементов, уровни сформированности знаний в соответствии с характеристикой деятельности будуших профессионалов.

Ключевые слова: уровни эффективности, организаџии учебной деятельности, сочиальные педагоги.

In the article the educational levels of the organization's effectiveness eyatelnosti future social workers. Characterized by a group of educational elements, the levels of formation of knowledge in accordance with the characteristics of future professionals.

Key words: levels of efficiency, organization of training activities and social workers.

Ініційований у межах трансєвропейського освітнього простору принцип неперервної освіти вимагає переосмислення теорії та практики організації навчальної діяльності майбутніх соціальних педагогів, оскільки набуває актуальності процес соціалізації всіх соціальних суб'єктів, а соціальнопедагогічний вплив визначається як процес цілеспрямованого 